\title{
Modeling The Types of Online Learning Media Using Multiple Linear Regression Analysis
}

\author{
Isma Muthahharah ${ }^{1}$, Inayanti Fatwa ${ }^{2}$ \\ Departement of Mathemtics Education, STKIP Pembangunan Indonesia, Indonesia
}

\begin{tabular}{|c|c|}
\hline Article Info & ABSTRACT \\
\hline Article history: & The research objective is to model the types of learning media WhatsApp Group, Google Classroom, \\
\hline Received : 09-16-2021 & Zoom and YouTube with multiple linear regression analysis. Multiple linear regression analysis is a \\
\hline Revised : :10-15-2021 & linear regression model with one continuous variable and $\mathrm{k}$ (two or more) independent variables. This \\
\hline Accepted : 10-18-2021 & $\begin{array}{l}\text { type of research is quantitative research that can model several types of online learning. The object } \\
\text { of study in this research is STKIP Pembangunan Indonesia students with a sample of } 25 \text { people. The }\end{array}$ \\
\hline Keywords: & source of data comes from primary data by giving questionnaires to students. Based on the results \\
\hline $\begin{array}{l}\text { Linear Regression; } \\
\text { WhatsApp Group; } \\
\text { Google Classroom; } \\
\text { Zoom; } \\
\text { Youtube. }\end{array}$ & $\begin{array}{l}\text { of the analysis, the type of online learning model obtained is }=70,376+0,357 x_{1}+0,322 x_{2}- \\
0,279 x_{1}-0,321 x_{2}+\varepsilon \text { with a contribution of } 21.2 \% \text {. From the resulting regression model, the best } \\
\text { learning models or those often used by Lecturers at STKIP development are WhatsApp Group and } \\
\text { Google Classroom. In addition to multiple linear regression analysis, other methods can also be used } \\
\text { to model types of online learning media with the addition of media such as LMS Moodle, Edmodo and } \\
\text { others. }\end{array}$ \\
\hline
\end{tabular}

Accredited by Kemenristekdikti, Decree No: 200/M/KPT/2020 DOI: https://doi.org/10.30812/varian.v5i1.1459

Corresponding Author:

This is an open access article under the CC BY-SA license.

Isma Muthahharah,

Departement of Mathematics Education, STKIP Pembangunan.

Email: muthahharahisma@gmail.com

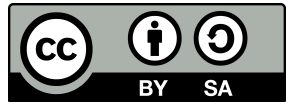

\section{A. INTRODUCTION}

Mobile technology has a major contribution in the world of education, especially in achieving online learning goals (Ali Sadikin, 2019). Technological advances can make it easier to use the internet to obtain subject matter with videos, get support during the online learning process, increase knowledge, and add to the learning experience. Each university has special considerations regarding which learning is suitable and easy for students to understand (Zhafira et al., 2020). Especially during the current covid19 pandemic, the government requires students to study from home so that students can get subject matter, so the existence of mobile technology provides solutions through the use of social media as a means to support online learning. The use of online learning is as an independent learning and requires student activity and provides various experiences through text, audio. videos that are used to obtain information, upload, download, send comments, use chat rooms, and video conference links to interact directly (Handayani et al., 2020). Various online media that are often used in online learning are WhatsApp Group, Google Classroom, Youtube, Zoom, LMS Moodle, Edmodo and others. Based on the results of research (Kristina et al., 2020). Online learning that is mostly done is online learning using WhatsApp as much as $87.2 \%$. Google Classroom as much as $41.3 \%$, Youtube as much as $15.7 \%$, Zoom as much as $13.8 \%$ and other applications $12.5 \%$, this shows that the majority of online learning used during the Covid-19 pandemic is WhatsApp Group, because it is considered practical and familiar and easy to use. Besides being supported by research results, in real conditions, lecturers mostly use WhatsApp Groups, but there are also those who use various other online media as previously mentioned. No previous research has modeled the types of learning that exist only in the form of percent, so in this study we will model the types of online learning that are often used on the STKIP Pembangunan campus, including WhatsApp Group, Google 
Classroom, Zoom, and Youtube. associated with student learning outcomes. Student learning outcomes are evaluations carried out by lecturers after providing material through online learning media. Learning outcomes need to be improved because several online media are already available or applications are used by students to get learning materials (Gunawan, 2020). The analysis used to model the types of online learning is multiple linear regression analysis. Multiple linear regression analysis is a multivariate technique that can determine the effect of independent variables on the dependent variable and can model several independent variables.

\section{B. LITERATURE REVIEW}

\section{Multiple Linear Regression Analysis}

Multiple linear regression analysis is a linear regression model with one continuous variable and $\mathrm{k}$ (two or more) independent variables. The collected data was processed using multiple linear regression models. The multiple linear regression formula is as follows (Harlan, 2018):

$$
y=\beta_{0}+\beta_{1} x_{1}+\beta_{2} x_{2}+\beta_{3} x_{3}+\beta_{4} x_{4}+\varepsilon
$$

Where:

$y \quad=$ Learning Outcames

$x_{1} \quad=$ WhatsApp Group learning media

$x_{2} \quad=$ Google Clasroom learning media

$x_{3} \quad=$ Zoom learning media

$x_{4} \quad=$ Youtube learning media

$\beta_{0} \quad=$ Constant

$\beta_{1}, \beta_{2}=$ Regression coeffiecient

$\varepsilon \quad=$ Error

Classical assumptions are the conditions that must be met in the regression model for the model to be valid. The classic assumption tests that are often used are (Mona et al., 2015):

a. Normality Test

The purpose of the normality test is to test whether in a regression model, the dependent variable and the independent variable or both have a normal distribution or not. A good regression model is a normal distribution or close to normal. Normality detection is done by looking at the Normal P-P Plot graph.

b. Heteroscedasticity Test

Heteroscedasticity test was conducted to test whether in a regression model, the residual variance inequality from one observation to another observation remained constant. Detection of heteroscedasticity is done by looking at the Scaterplot graph.

c. Multicollinearity Test

Multicollinearity test aims to detect whether the independent variables in the regression model are correlated with each other. To meet the BLUE criteria, there is no correlation between any independent variables in the regression model. One way to detect multicollinearity symptoms is to look at the VIF value, that is, if the VIF value is $<10$ or vice versa by looking at the tolerance value $>0.1$ (Sutisna and Triyono, 2016).

\section{Coefficient of Determination}

The coefficient of determination explains the variation in the effect of the independent variables on the dependent variable. Or it can also be said as the proportion of the influence of all independent variables on the dependent variable. The value of the coefficient of determination can be measured by the value of RSquare or Adjusted R-Square (Kurniasari et al., 2020).

\section{Online Learning Media on Learning Achievement}

Online learning media can be interpreted as media equipped with a controller that can be operated by the (user) so that the user (user) can control and access what is needed. In this study, there were 4 online learning media used, namely (Herliandry et al., 2020): 
a. WhatsApp Group Learning Media

WhatsApp Group is an internet-based application in WhatsApp and is one of the most popular impacts of the development of information technology (Prajana, 2018). WhatsApp can also be used to exchange information, besides WhatsApp can send and receive not only in text but also in the form of images, videos, audio and other files in unlimited quantities. The WhatApps application, especially the WhatsApps Group feature, is considered ideal to be used as a means of student discussion and dissemination of information in the university environment (Susilawati and Supriyatno, 2020).

b. Google Classroom Learning Media

Google Classroom is a Learning Management System (LMS) issued by the Google company, so it is integrated with other Google products such as Gmail Drive, Hangout, Meet, Youtube, and calendar. This LMS can also be used to deliver teaching materials and provide tests that are integrated with assessments. Students can access it through any browser on desktop and mobile devices (Android and Apple). Suitable for lecturers who need to open online classes. Google classroom aims to facilitate the delivery of material without face-to-face that can be accessed via Laptop and HP (Zailani et al., 2020).

c. Zoom Learning Media

Zoom is an application that can simplify the online learning process. Zoom can accommodate several participants in a meeting and is often used in face-to-face lectures in the online room system (Monica and Fitriawati, 2020). The Zoom application can be used on both desktop and mobile devices.

d. Youtube Learning Media

Youtube is a site that loads, watches various entertainment videos, as well as learning videos that can be shared on social media (Fatty Faiqah, Muh. Nadjib, 2015). In fact, many academics have made material in the form of videos so that students can understand the material quickly through the steps given. Youtube can also be accessed via desktop devices and mobile phones.

After discussing the description of the learning media, then the learning outcomes will be discussed. Learning outcomes are changes in abilities that include cognitive, affective, and psychomotor abilities. Learning achievement is a measure of the success of students in carrying out learning activities. Learning achievement can be obtained with the test device. The test results can provide information on abilities or changes in behavior from learning outcomes. Learning achievement can be used as a tool to evaluate learning (Pirantika, A. Purwanti, 2017).

\section{RESEARCH METHOD}

\section{Variety of research}

This type of research is quantitative research that can model several types of online learning.

\section{Study Object}

The object of study in this research is STKIP Pembangunan Indonesia students with a sample of 25 people. The source of data comes from primary data by giving questionnaires to students.

\section{Research variable}

The research variables used are:

$y=$ Learning Outcames

$x_{1}=$ WhatsApp Group learning media

$x_{2}=$ Google Clasroom learning media

$x_{3}=$ Zoom learning media

$x_{4}=$ Youtube learning media

\section{Research procedure}

The stages of the research carried out are:

a. Describing the data.

b. Doing modeling with multiple linear regression analysis.

c. Determine the coefficient of determination.

d. Making interpretations and concluding research results. 


\section{RESULT AND DISCUSSION}

The results of the research from the data used are the results of all online learning media variables, namely WhatsApp Group, Google Classroom, Zoom and Student Learning Outcomes. The descriptive statistical analysis of each online learning media variable is presented in Table 1.

Table 1. Descriptive Statistics of Online Learning Media Data

\begin{tabular}{lccccc}
\hline & N & Minimum & Maximum & Mean & Std. Deviation \\
\hline WhatsApp Group & 25 & 17 & 40 & 30,76 & 6,240 \\
Google Clasroom & 25 & 14 & 34 & 24,80 & 5,795 \\
Zoom & 25 & 14 & 33 & 24,92 & 5,090 \\
Youtube & 25 & 17 & 40 & 26,76 & 5,747 \\
Hasil Belajar & 25 & 55 & 90 & 73,80 & 8,201 \\
\hline
\end{tabular}

In Table 1 it can be seen that the number of data $(\mathrm{N})$ is all the same, namely 25 . The data types of learning media that have the minimum value (lowest value) are WhatsApp Group 17, Google Classroom 14, Zoom 14, Youtube 17, and Learning Outcomes 55, while the miximum values (highest data) are WhatsApp Group 40, Google Classroom 34, Zoom 33, Youtube 40, and learning outcomes 90. The average value (Mean) for WhatsApp Group is 30.76; Google Class 24.80; Zoom 23.90, and Youtube; 26.78. From the highest average value (Mean) is WhatsApp Group, it can be said that the best learning model used by students is WhatsApp Group, because WhatsApp Group is the easiest social media to use and does not require a large data quota. The highest standard deviation is also in the WhatsApp Group, because it has a value of 6,240. Standard deviation that describes the diversity of the types of learning media used.

Before finding the multiple linear regression model, the classical assumption test was first tested with the following description:

a. Normality test

The normality test can be seen from the following Normal P-P Plot:

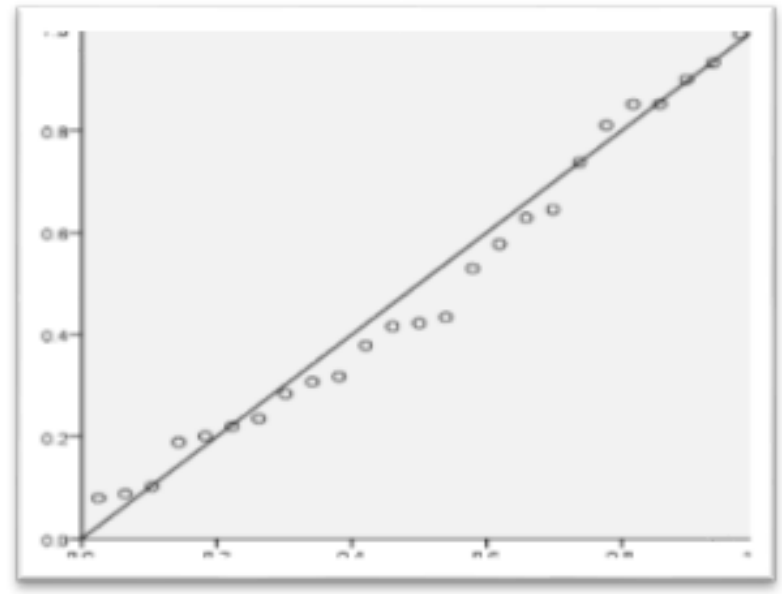

Figure 1. Normal P-Plot Residual

From Figure 1 it can be seen that the distribution of the data is relatively around the line, thus it can be concluded that the residuals of the multiple linear regression model are normally distributed.

b. Multicollinearity Test

The multicollinearity test is determined by a value with a VIF value $<10$ or vice versa by looking at the tolerance value $>0.1$ which is shown in Table 2. 
Table 2. Multicollinearity Test

\begin{tabular}{|c|c|c|c|}
\hline & \multirow{2}{*}{ Model } & \multicolumn{2}{|c|}{ Collinearity Statistics } \\
\hline & & Tolerance & VIF \\
\hline \multirow{4}{*}{1} & WhatsApp Group & 0,762 & 1,312 \\
\hline & Google Clasroom & 0,901 & 1,109 \\
\hline & Zoom & 0,759 & 1,317 \\
\hline & Youtube & 0,895 & 1,117 \\
\hline
\end{tabular}

c. Heteroscedasticity Test

Heteroscedasticity test can be seen from the following Scatterplot graph:

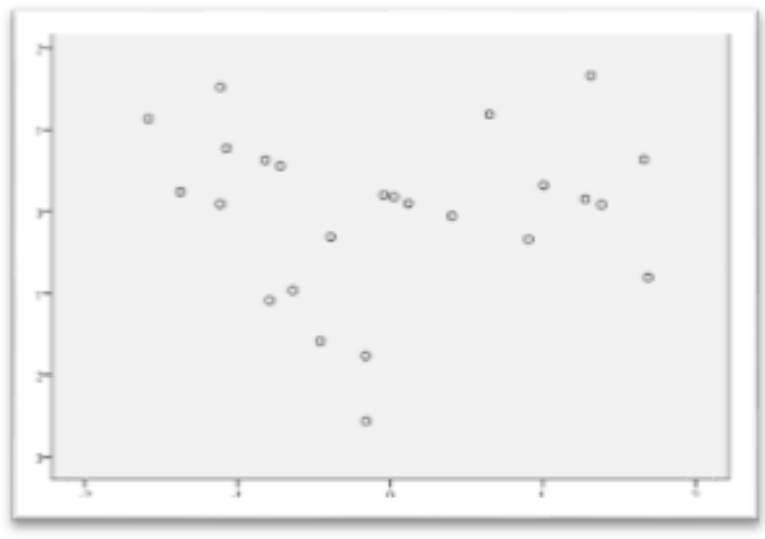

Figure 2. Scatterplot

From Figure 2 it can be seen that the distribution of data does not form a certain pattern, thus it can be concluded that there is no heteroscedasticity in the regression model.

After fulfilling the classical assumption test, the multiple linear regression coefficient values can be seen in Table 3 .

Table 3. Coefficient of Multiple Linear Regression

\begin{tabular}{llcc}
\hline \multirow{2}{*}{ Model } & \multicolumn{2}{c}{ Unstandardized Coefficients } \\
& B & Std. Error \\
\hline \multirow{2}{*}{\begin{tabular}{l} 
(Constant) \\
\multirow{2}{*}{ WhatsApp Group }
\end{tabular}} & 70,376 & $18 ., 63$ \\
& Google Clasroom & 0,357 & 0,293 \\
& Zoom & $-0,322$ & 0,290 \\
& Youtube & $-0,321$ & 0,360 \\
\hline
\end{tabular}

From Table 3, multiple linear regression models can be formed as follows:

$$
y=70,376+0,357 x_{1}+0,322 x_{2}-0,279 x_{1}-0,321 x_{2}+\varepsilon
$$

Based on multiple linear equations, it can be explained that the Constant is 70.376; it means that if WhatsApp Group, Google Classroom, Zoom, Youtube, are 0, then the learning result is 70,376. WhatsApp Group variable regression coefficient is 0.357; it means that if the other independent variables remain and the WhatsApp Group has increased by one point, then the learning outcome increased by 0.357 . Google Classroom variable regression coefficient is 0.322 ; it means that if the other independent variables are fixed and Google Classroom has increased by one point, then learning outcomes have increased by 0.357 . Zoom variable regression coefficient is -0.279 ; it means that if the other independent variables are fixed and Zoom) has increased by one point, then the learning result, experienced a decrease of -0.279 ; Youtube variable regression coefficient is -0.321 ; it means that if the other independent variables are fixed and youtube has added one point, then the learning outcome has decreased by -0.321 . 
The regression coefficient of the WhatsApp Group and Google Classroom variables is positive because in the implementation of learning, lecturers at STKIP Pembangunan more often use these two media to provide material because practicals are used and do not use too much quota, while the regression coefficient for Zoom and Youtube have negative values because in the implementation of learning only a few lecturers provide material through the two media and they are rarely used because they require a large data quota and a good connection to enjoy the media, while students are also in areas where the internet connection is not very supportive in receiving the material given by the lecturer.

To find out how big the contribution of the type of learning media is, if WhatsApp Group, Google Classroom, Zoom, Youtube, to learning outcomes, the coefficient of determination or value ( $\mathrm{R}$ suare) is used. shown in Table 4.

Table 4. Determinant Coefficient

\begin{tabular}{ccccc}
\hline Model & R & R Square & Adjusted R Square & Std. Error of The Estimate \\
\hline 1 & 0,460 & 0,212 & 0,054 & 7.974 \\
\hline
\end{tabular}

From Table 4, it can be seen that the R square value for the regression model is 0.212 , which can be concluded that the contribution of learning media, namely WhatsApp Group, Google Classroom, Zoom, Youtube is $21.2 \%$.

\section{E. CONCLUSION AND SUGGESTION}

Based on the results of the analysis, the type of online learning model obtained is $y=70,376+0,357 x_{1}+0,322 x_{2}-$ $0,279 x_{1}-0,321 x_{2}$ with a contribution of $21.2 \%$. From the resulting regression model, the best learning models or those often used by Lecturers at STKIP development are WhatsApp Group and Google Classroom. In addition to multiple linear regression analysis, other methods can also be used to model types of online learning media with the addition of media such as LMS Moodle, Edmodo and others.

\section{ACKNOWLEDGEMENT}

Acknowledgments are addressed to the Ministry of Research, Technology and Higher Education for providing research grants and also to the Indonesian Development STKIP who have provided support so that this research can be realized properly.

\section{REFERENCES}

Ali Sadikin, A. H. (2019). Pembelajaran Daring di Tengah Wabah Covid-19. Indonesian Journal of Islamic Education, 6(2):187192.

Fatty Faiqah, Muh. Nadjib, A. S. A. (2015). Youtube Sebagai Sarana Komunitas Makassarvidgram. Komunikasi Kareba, 16(1):2842.

Gunawan, I. (2020). Peningkatan Hasil Belajar Daring Peserta Didik Selama Pandemi Covid-19 Melalui Pemanfaatan Fitur Aplikasi Zoom di SD Negeri 77 Palembang. Inovasi Sekolah Dasar, 7(2):152-163.

Handayani, T., Khasanah, H. N., and Yoshinta, R. (2020). Pendampingan Belajar Di Rumah Bagi Siswa Sekolah Dasar Terdampak Covid-19. Jurnal Pengabdian kepada Masyarakat, 1(1):107.

Harlan, J. (2018). Analisis Regresi Linear. Journal of Chemical Information and Modeling, 53(9):1-119.

Herliandry, L. D., Nurhasanah, Suban, M. E., and Heru, K. (2020). Transformasi Media Pembelajaran Pada Masa Pandemi Covid19. Jurnal Teknologi Pendidikan, 22(1):65-70.

Kristina, M., Sari, R. N., and Nagara, E. S. (2020). Model Pelaksanaan Pembelajaran Daring Pada Masa Pandemi Covid 19 Di Provinsi Lampung. Idaarah: Jurnal Manajemen Pendidikan, 4(2):200.

Kurniasari, A., Pribowo, F. S. P., and Putra, D. A. (2020). Analisis Efektivitas Pelaksanaan Belajar Dari Rumah (Bdr) Selama Pandemi Covid-19. Jurnal Review Pendidikan Dasar: Jurnal Kajian Pendidikan dan Hasil Penelitian, 6(3):1-8.

Mona, M., Kekenusa, J., and Prang, J. (2015). Penggunaan Regresi Linear Berganda untuk Menganalisis Pendapatan Petani Kelapa. Studi Kasus: Petani Kelapa Di Desa Beo, Kecamatan Beo Kabupaten Talaud. Jurnal Matematika dan Aplikasi, $4(2): 196$. 
Monica, J. and Fitriawati, D. (2020). Efektivitas Penggunaan Aplikasi Zoom Sebagai Media Pembelajaran Online Pada Mahasiswa Saat Pandemi Covid-19. Jurnal Communio : Jurnal Jurusan Ilmu Komunikasi, 9(2):1630-1640.

Pirantika, A. Purwanti, R. (2017). Peningkatan Aktivitas Dan Hasil Belajar Dengan Metode Problem Basic Learning (PBL) Pada Mata Pelajaran Tune UP Motor Bensin Siswa Kelas XI di SMK Insan Cendekia Turi Sleman Tahun 2015/2016. Universitas Nusantara PGRI Kediri, 01(1):1-7.

Prajana, A. (2018). Pemanfaatan Aplikasi Whatsapp dalam Media Pembelajaran di UIN Ar-Raniry Banda Aceh. Cyberspace: Jurnal Pendidikan Teknologi Informasi, 2(2):3.

Susilawati, S. and Supriyatno, T. (2020). Online Learning Through WhatsApp Group in Improving Learning Motivation in the Era and Post Pandemic COVID -19. Jurnal Pendidikan: Teori, Penelitian, dan Pengembangan, 5(6):852.

Sutisna, A. and Triyono, M. B. (2016). The Learning Effectiveness of the Students in Smk 2 Negeri Wonosari Gunung Kidul Yogyakarta. Jurnal Pendidikan Teknologi dan Kejuruan, 23(2):111.

Zailani, A. U., Agung, A., Agung, N., Sholihin, S., and Samsoni, S. (2020). Sosialisasi Google Classroom Sebagai Media Pembelajaran Online Akibat Dampak Pandemic Covid 19 Di Smpit Al-Mustofa. Jurnal Pusat Pengabdian Kepada Masyarakat, 4(2):23.

Zhafira, N. H., Ertika, Y., and Chairiyaton (2020). Persepsi Mahasiswa Terhadap Perkuliahan Daring Sebagai Sarana Pembelajaran Selama Masa Karantina Covid-19. Jurnal Bisnis dan Kajian Strategi Manajemen, 4:37-45. 
